\title{
Does the impact of IFRS on audit fees differ between early and late adopters?
}

\author{
Vincent Konadu Tawiah
}

DCU Business School, Dublin City University, Dublin, Ireland

Impact of IFRS on audit fees

\begin{abstract}
Purpose - This study aims to examine whether the impact of international financial reporting standards (IFRS) on audit fees differs between early and late adopters.

Design/methodology/approach - The authors use robust econometric estimation on a sample of 314 firms from both early and late IFRS adopting countries.

Findings - The authors find that IFRS is positively and significantly associated with an increase in audit fees for early adopters, but the impact is very weak for late adopters and insignificant in some cases. The results on auditing time suggest that increase in audit fees around IFRS adoption is due to an increase in audit reporting lags. After accounting for pre- and post-years, the authors find that the relationship between IFRS and audit fees, as well as audit time for late adopters, is significant only in the adoption year. However, early adopters experience a significant increase in audit fees and audit time in the transition year to one-year postadoption.
\end{abstract}

Practical implications - The findings imply that countries that are yet to adopt IFRS are less likely to experience a significant increase in audit fees audit time. Hence, is probable that the benefit of IFRS will outweigh the cost.

Originality/value - The results, therefore, suggest that early adopters paid a premium for been the first users of IFRS, which is consistent with any innovation. The study provides new insights by demonstrating that the consequences of IFRS differ between early and late adopters.

Keywords Africa, IFRS, Audit fees, Early adopters, Audit reporting lags, Late adopters

Paper type Research paper

\section{Introduction}

Although there is considerable literature on the effect of international financial reporting standards (IFRS) on the auditing market, these studies are limited in explaining how the effect differs between early and late adopters (De George et al., 2013; Dinh and Piot, 2014; Griffin et al., 2009; Kim et al., 2012; Risheh and Al-Saeed, 2014; Yaacob and Che-Ahmad, 2012). Additionally, existing studies largely ignore Africa, probably due to the low adoption of IFRS[1] but with a unique mix of early and late adopting countries (Boolaky et al., 2020). For example, most southern African countries, such as Zimbabwe, Botswana and South Africa started using IFRS before or around the same time of European union (EU) adoption whiles few West African countries adopted it from 2010 onwards with the bulk of remaining non-adopters as of 2018.

(C) Vincent Konadu Tawiah. Published by Emerald Publishing Limited. This article is published under the Creative Commons Attribution (CC BY 4.0) licence. Anyone may reproduce, distribute, translate and create derivative works of this article (for both commercial and non-commercial purposes), subject to full attribution to the original publication and authors. The full terms of this licence maybe seen at http://creativecommons.org/licences/by/4.0/legalcode 
IJAIM 30,1

Therefore, in this paper, we examine the effect of IFRS adoption on audit fees and audit timing with specific reference to early and late adopters in Africa. We argue that the difference in adoption timing provides new insights on the consequences of IFRS between early and late adopters. As argue by Key and Kim (2020), late adopters have different incentives and exposure to IFRS reporting before adoption; hence, the effect can differ from early adopters. Also, given that the audit market and financial reporting environment of most African countries is significantly different from other countries (Elbannan, 2011; Lassou and Hopper, 2016; Khlif and Samaha, 2014; Agyei-Boapeah et al., 2020), this analytical study on Africa extends the literature.

In a bid to provide this new insight(s), we use a sample of 1,570 firm-year observations (314 firms over five years) from Nigeria and South Africa to provide a comparative analysis between early and late IFRS adopters. We focus on these two countries because of the significant difference in the adoption years between the two countries. South Africa was among the early adopters of IFRS in 2005, as opposed to Nigeria adoption in 2012, and thus labelled as late adopters. Despite the differences in the adoption year, both countries share a common similarity of been among the largest economies in Africa with a strong accounting environment.

Consistent with our expectation, we find that the effect of IFRS on audit fees and auditing time differ between early and late adopters. We find that IFRS is positively and significantly associated with an increase in audit fees for early adopters, but the impact is very weak for late adopters and insignificant in some cases. Similarly, the results show a significant increase in auditing time around IFRS adoption for early adopters. However, in the case of late adopters, although auditing time increases, it is barely significant. In further analyses, we find that the positive relationship between IFRS and audit fees and auditing time is significant in transition year through to one-year post-IFRS adoption. But in the case of late adopters, the relationship is significant at only adoption year. The results on auditing time provide an understanding that an increase in audit fees around IFRS adoption is due to an increase in auditing time. Our findings, therefore, suggest that early adopters paid a premium for been the first users of IFRS, which is consistent with any innovation. The results are robust to the alternative measurement of audit fees and auditing time.

The findings of late adopters shed new light on how the cost and benefit of IFRS vary for adopters at different timing. More distinctively, unlike past studies (Cameran and Perotti, 2014, on Italy; De George et al., 2013, on Australia; Dinh and Piot, 2014, on Europe; Griffin et al., 2009; Higgins et al. (2016) on New Zealand; Hassan et al., 2014, on the UK; Isaboke and Chen (2019 Lin and Yen (2016) on China; Rished and Al-Saeed, 2014; on Jordan; Yaacob and Che-Ahmad, 2012, on Malaysia), which are limited to only early adopters, we extend the analysis by covering late adopters for the first time in the literature. By presenting a comparative analysis between early and late adopters, the timing of adopting any new accounting system is likely to result in different outcomes.

Another point of difference in our paper is that we use the same firm-level data set for the same period to investigate the IFRS-auditing effect as opposed to prior studies where the impact of IFRS on audit fees and auditing time were analysed using different data sets and period. Hence, it does not provide a reliable and relevant basis for comparative and compelling evidence. We submit that the two are related; hence, a single data set provides more compelling evidence than different settings for each. By analysing the two effects simultaneously, we provide a fair and robust explanation that the increase in audit fees around IFRS adoption is due to a significant increase in auditing time.

In summary, we extend the IFRS-auditing effect by showing that the impact of IFRS on auditing differs among early and late adopters. We attribute this contrasting finding 
between early and late adopters to experience, exposure and incentive to adopt IFRS. Early adopters had intrinsic value to adopt IFRS for transparency and comparability, hence investing heavily to realise such benefits (Capkun et al., 2016). Late adopters, on the other hand, were probably influenced by the external forces and the global drive for accounting harmonisation, leading to less interest in investing more money and time in the implementation of IFRS. What is more, early adopters did not have much exposure and experience to IFRS compare with late adopters, where some auditors might have work on the IFRS system in other countries. This is particularly true in the case of Africa, where the Big4, which has a global network of accounting firms, audit more than $80 \%$ of the listed firms.

In addition to extending the literature to late adopters, we also contribute to the scanty research on accounting in Africa, a growing continent but often neglected in the literature. To the best of our knowledge, our study is the first to provide a comprehensive analysis of the effect of IFRS on the audit market, focussing on early and late adopters in Africa.

The remainder of the paper is structured as follows. Section 2 provides a brief background of the auditing market in the sample countries. We present a review of the literature in Section 3. Section 4 describes the research methods, and Section 5 presents results and discussion on the findings. The paper concludes in Sections 6 and 7.

\section{Brief background of the auditing market in South Africa and Nigeria}

South Africa, one of the leaders in terms of strong auditing and accounting reporting environment, have an interesting audit market compare to its peers in Western countries. As of 2016, there were about 41,000 registered chartered accountants and 2000 active accounting firms with 4,283 qualified registered auditors[2] (Research and Markets, 2019). However, according to the Independent Regulatory Board for Auditors (IRBA), more than $86 \%$ of large and listed companies in South Africa were audited by the Big4 in 2016, with PWC auditing more than $40 \%$ of these companies compare with $70 \%$ Big 4 market share in Western countries (Independent Regulatory Board for Auditors, 2016). Out of the 4,283 qualified audit professionals, more than $60 \%$ work in the Big4 firms. The impact of South African apartheid is also evidence in the audit market. Only $10.5 \%$ of the registered auditors are black Africans.

To curb the growing market concentration of the Big4 in South Africa, the IRBA introduced mandatory audit firm rotation that will require companies to switch auditors every 10 years, effective from 2023 (Independent Regulatory Board for Auditors, 2016). This is in addition to the existing requirement of mandatory rotation of audit partners every five years. While IRBA argues that the rotation will improve audit quality, increase competition and empower black accountants, the leaders of the Big4 argue that the rotation will not necessarily reduce concentration because the large companies will appoint a Big4 firm every 10 years (Harber and West, 2017). Harber and Marx (2019) find that the audit committee and shareholders are not likely to appoint mid-tier firms as auditors even under the mandatory firm rotation.

Among the top audit firms are some local firms, such as SekelaXabiso, Sizwentsalubagobodo and Theron du Plessis Durbanville. The accounting sector generates about R29bn included the business services sector $20 \%$ contribution to gross domestic product. About 56,000 people work in the accounting service sector as professional accountants or support staff (Research and Markets, 2019). Due to recent auditing scandals such (e.g. KPMG - Gupta family, VBS Mutual Bank) in the country, it is perceived that South Africa is losing its spot as a global leader in auditing and financial reporting in Africa (Research and Markets, 2019). 
IJAIM 30,1

Nigeria, as one of the fastest developing African countries, mimics the audit market of South Africa with some dynamic. Although Nigeria is the most populated country in Africa, it has less than 1,500 registered audit firms compare with about 2000 in South Africa. However, Nigeria has more than 60,000 chartered accountants, which is higher than South Africa but less than developed countries such as the UK. Similar to market concentration in most African countries, the Big4 audit about 85\% of public interest companies in Nigeria (Asien, 2014), with PWC being the market leader. By large, Nigeria and South Africa have a common audit market except for the difference in IFRS adoption timing. Hence, both countries provide a unique setting for assessing the impact of IFRS adoption on the audit market between early and late adopters.

The aforementioned discussion shows that the auditing market in Africa is different from most western countries in prior studies. For instance, Globally, the audit market is highly concentrated around the Big4. However, compared with developed countries where the Big4 services less than 75\%[3] of the market (Gerakos and Syverson, 2015; Velte and Stiglbauer, 2012), in South Africa and Nigeria, the Big4 hold audit more than $90 \%$ of the listed companies. This sharp contrast provides a unique setting for examining the impact of IFRS on the Africa audit market. In addition, there is a variation of market share among the Big4. For example, in South Africa, PWC has the largest audit market share in South Africa, with a $40 \%$ market share, which is uncommon in most western countries such as the UK. Also, the sizes of non-Big10 firms in Africa are very small compared with those in other developed countries. In Nigeria, most mid-tier to large audit firms are run by only 1-2 partners ((Asien, 2014).

\section{Theoretical background}

Theoretically, prior studies suggest that audit fee is a function of auditor's liability losses and cost of time (Simunic (1980). Both liability losses and auditing time depend on the business risk of the client. Consequently, Seetharaman Gul and Lynn (2002) show a positive relationship between a firm's business risk and audit fees. One major component of business risk is the regulatory framework; hence, Vieru and Schadewitz (2010) found that changes in regulations, including accounting disclosures, is likely to affect audit fees. Changes in accounting standards can cause delays in the preparation and auditing of financial statements. To the preparers, the adoption comes with a radical modification of the firm's existing accounting system. Hence, management needs to adapt to a new approach to prepare a financial statement that will require extra time. Invariably, delay in preparing financial statements directly delay management submissions to and discussions with auditors (Bonson-Ponte et al., 2008). Such delays signal an increase in business risk and, consequently, possible auditor's liability losses.

As principle-based and market-oriented standards, auditors will have to spend additional time evaluating and verifying managerial judgements, especially on items, such as intangible assets and financial instruments. Hence, auditors will require extra resources to verify management assertion and estimates, which invariably increases audit fees. Further, the principle-based nature of IFRS limit auditors to gather specific evidence, thereby increasing potential auditor's liability losses if the audit fails (Diehl, 2010).

Although some prior studies have demonstrated the value relevance of IFRS in improving reporting quality, the subjectivity of measurement under IFRS makes it risky and time-consuming to audit IFRS financial statements (Dayanandan et al. (2016) Houqe, 2018; Isaboke and Chen, 2019; Liu et al., 2011). In effect, the complexity and principle-based nature of IFRS will require high audit fees to compensate for the increase in auditing time 
and possible litigation that may arise due to undiscovered misstatements (Cameran and Perotti, 2014; De George et al., 2013; Kim et al., 2012).

\section{Impact of IFRS} on audit fees

\section{Literature review}

\subsection{International financial reporting standards and audit fees}

It is argued that IFRS adoption tends to precipitate an increase in auditing fees due to the increase in effort and time required for auditors (and firms) to address the relatively detailed and complex requirements of IFRS. Extant literature has revealed the increasing cost of audit services after IFRS adoption in some countries (Cameran and Perotti, 2014, on Italy; De George et al., 2013; Miah et al. (2020) on Australia; Griffin et al., 2009; Higgins et al. (2016) on New Zealand; Hassan et al., 2014, on the UK; Lin and Yen (2016) on China; Rished and A1Saeed, 2014; on Jordan; Yaacob and Che-Ahmad, 2012, on Malaysia). Although many African countries have been progressively embracing IFRS (Bruce, 2011), the consequences of IFRS adoption on the audit market in these countries have not been quantified.

In a cross-country analysis of European countries, Kim et al. (2012) find that audit fees increase from 2005 and audit fee premium increases with IFRS adoption and decreases with the improvement in financial statement quality due to IFRS adoption. Similarly, Griffin et al. (2009) study revealed an increase in audit fees is higher in the second and third years following IFRS adoption than the years that preceded the adoption and the adoption year.

Extending the debate of IFRS adoption and audit fees in Australia, De George et al. (2013) find a significant positive impact of IFRS adoption on audit fees due to high equity adjustments. Similarly, Yaacob and Che-Ahmad (2012) find a positive association between IFRS adoption and increased audit fees among Malaysian companies. Vieru and Schadewitz (2010) also find that both audit and non-audit fees paid to statutory external auditors increased significantly during the adoption period in Finland. Cameran and Perotti (2014) study on non-listed banks also indicates increasing audit fees due to IFRS adoption and especially for banks which are into derivatives and hedge accounting. Similarly, Hassan, et al. (2014) highlighted that in addition to the positive association between IFRS adoption and audit fees, non-Big4 clients are the hardest hit in terms of audit fees due to IFRS adoption in the UK. Contrary, Lin and Yen (2016) find that increases in audit fees are much more for Big4 clients after the implementation of IFRS in China. Consistent with Lin and Yen (2016), Choi and Yoon (2014) also demonstrated a significant increase in audit fees charged by the Big4 following IFRS adoption in South Korea. Rished and Al-Saeed (2014) also reported similar findings among Jordanian listed companies.

A recent study by Higgins et al. (2016) shows the increasing cost of auditing services even after IFRS adoption year. They argue that an increase in audit fees is not a short-term effect, as stated in prior studies. They also find marginal pricing during post-IFRS for PWC and Deloitte.

\subsection{International financial reporting standards and auditing time}

According to Blankley et al. (2014), auditing time is the days between a firm's financial yearend and the date an audit report is signed. Auditing time is one of the few externally observable audit output variables for gauging audit efficiency (Habib, 2015; De Martinis and Houghton, 2019). As suggested by Bamber et al. (1993), Auditing time affects the timeliness of both audit and earnings management, as well as provide more insights into audit efficiency.

As a critical area of research, some scholars provide some evidence on specific firm characteristics as determinants of auditing time (Basioudis et al., 2008; Habib, 2012). For instance, Bonson-Ponte et al. (2008) find that company size relative to its sector is a key 
IJAIM 30,1

determinant of auditing time, and more regulated companies have shorter auditing time than less regulated companies. Other studies have focussed on the characteristics of auditors as of auditing time. Knechel and Pyne (2001) find that the provision of non-audit services has a knowledge spillover effect that reduces auditing time. Also, the longer an auditor stay with a client, the shorter the auditing time (Lee, Mande and Son, 2009).

There are emerging factors associated with auditing time that are mainly related to regulatory changes, such as a change in listing rules; SOX 404 requirements (Ettredge et al., 2006; Lambert et al., 2013; Munsif et al., 2012; Afify, 2009) and the adoption of new accounting standard; Habib and Bhuiyan (2011) - auditing time in New Zealand; Habib (2015) - Chinese Accounting Standards and auditing time; Amirul and Salleh (2014) - IFRS and auditing time in Malaysia. Cho et al. (2015) - accruals quality and audit hours. Using a sample of 105 listed Spanish firms, Bonson-Ponte et al. (2008) find a significant positive association between IFRS adoption and auditing time. In a similar vein, Habib (2015) focusses on the Chinese context and finds that larger audit firms engaged in specific industries have a competitive advantage in shortening auditing time. This finding is consistent with early studies by Habib and Bhuiyan (2011) on firms in New Zealand.

Habib and Bhuiyan (2011) investigation into the impact of IFRS on auditing time in New Zealand, find a significant increase in auditing time following the adoption of IFRS, and this is also reflected in the study of Walker and Hay (2013), who examined the same research question in New Zealand and had similar results. In Malaysia, Amirul and Salleh (2014) used data on 257 listed firms to explain the relationship between auditing time and IFRS between 2009 and 2011. Consistent with prior studies, they found a significant positive association between IFRS and auditing time. Consequently, they concluded that Malaysia's convergence to IFRS has significantly increased the auditing time of listed companies.

Although all the above literature show that the adoption of IFRS increases audit fees and auditing time, they all focus on early adopting countries and do not provide insights on late adopters and how their experience differs from early adopters. Almost all the sample countries in prior studies adopted IFRS around the same time of 2005 (e.g. Australia, EU countries and New Zealand). We argue that the effect of IFRS on audit fees and auditing time might differ between early and late adopters because of the difference in incentives and exposure (Key and Kim, 2020). Firstly, similar to voluntary adopters, early adopters have more intrinsic value to adopt IFRS and were less likely to be pressured by international forces, such as the World Bank and international monetary fund (IMF) to adopt it. However, been pressured by external forces can leave firms unprepared, which could result in high audit fees and audit reporting time. Secondly, late adopters are more likely to have exposure to actual IFRS before actually adopting the standard reporting through the financial statements of early adopters. Specifically, global accounting firms are more likely to leverage their experience from early adopters to beat the competition on audit pricing and timing in late adopting countries. Nevertheless, having prior knowledge could be a source of high fees because accounting firms now have a grasp on what entails to transit to IFRS reporting.

Besides the fact that the existing study concentrates only on early adopters, these sample countries are highly developed countries with economic and market structures notably different from the weak market structures of Africa (Agyei-Boapeah et al., 2020); hence, these findings cannot be generalised by virtue of the lack of evidence in Africa.

\section{Research design}

\subsection{Sampling}

Although our objective is to investigate the impact of IFRS on the audit fees and audit lag in Africa, we focus our empirical analysis on South Africa and Nigeria for three reasons. 
Firstly, the stock markets for the two countries represent a significant proportion of listed companies in Africa (Tawiah and Boolaky, 2019). Secondly, these two countries adopted IFRS at different periods with seven years apart. South Africa adopted IFRS in 2005 whiles Nigeria adopted in 2012. Thirdly, the late adoption of IFRS by Nigeria is said to have been orchestrated by external forces - the World Bank and IMF (Zori, 2015), which is not the case in South Africa.

Following Capkun et al. (2016), we break the sample into early and late adopters. Early adopters are firms that adopt IFRS in 2005 while late adopters are firm that adopted after 2010. Thus, listed firms in South Africa are classified as early adopters, and listed firms in Nigeria are late adopters. Based on the design by Griffin et al. (2009), our sample period covers two years pre- and post-adoption period. As our sample is made of firms whose adoption year is different from the calendar year, we use even year analysis where IFRS-2, IFRS- 1 are pre-adoption periods, IFRS0 is the adoption period and IFRS +1 ; IFRS +2 are 2year post-adoption yielding 5-year firm-level data for 314 firms. The sample contains 195 early adopters and 119 late adopters, representing more than $60 \%$ of the listed firms in each country. The sample selection is based on the availability of data. Conducting crosssectional comparisons between early and late adopters provide more comprehensive evidence on the consequence of IFRS in developing countries (Capkun et al., 2016). Due to inadequate information on African firms in many databases, we hand-collected all data from annual reports of firms. The industry distribution is presented in Appendix.

Audit fee is measured by the natural logarithm of total annual audit fees paid. Auditing time measures the period from the balance sheet date and the signature date of the audit report and is an indicator of audit efficiency.

\subsection{Model specification}

Following prior studies (Higgins et al., 2016; Griffin et al., 2009), we rely on an audit model with a temporal indicator and prior predictor variables as controls to examine the impact of IFRS adoption on audit fees and auditing time. Contrary to De George (2013), Griffin et al. (2009), Kim et al. (2012), who used cross-section pooled regression models, our model is specified as a time-series panel regression.

$$
\begin{aligned}
\text { Audit fees } i t= & a+\beta_{1}(\text { IFRS })_{i t}+\delta_{2}(\text { Audit lags })_{i t}+\delta_{3}(\text { Auditor switch })_{i t}+\delta_{4}(\text { Big4 })_{i t} \\
& +\delta_{5}(\text { Firm size })_{i t}+\delta_{6}(\text { Profitability })_{i t}+\delta_{7}(\text { Return on assets })_{i t} \\
& +\delta_{8}(\text { Leverage })_{i t}+\varepsilon_{i t}
\end{aligned}
$$

$$
\begin{aligned}
\text { Audit lags }_{i t}= & a+\beta_{1}(\text { IFRS })_{i t}+\delta_{2}(\text { Audit fees })_{i t}+\delta_{3}(\text { Auditor switch })_{i t}+\delta_{4}(\text { Big } 4)_{i t} \\
& +\delta_{5}(\text { Firm size })_{i t}+\delta_{6}(\text { Profitability })_{i t}+\delta_{7}(\text { Return on assets })_{i t} \\
& +\delta_{8}(\text { Leverage })_{i t}+\varepsilon_{i t}
\end{aligned}
$$

We admit that the binary nature of post-IFRS observations creates bias results due to the combining effects of transitional and learning costs of adoption. To overcome this limitation in estimating the long-term effects of IFRS adoption, we follow Higgins et al. (2016) and modify equation (1) by replacing the independent variable of interest (IFRS) with the 
IJAIM

30,1

following variables.IFRS-1 a binary variable equal to 1 if the year prior to adoption or 0 otherwise.IFRS - binary variable equal to 1 if it is the year of IFRS adoption or 0 otherwise. IFRS +1 = binary variable equal to 1 if is one year after IFRS adoption or 0 otherwise. IFRS + 2 = a binary variable equal to 1 if is two years after IFRS adoption or 0 otherwise.

$$
\begin{aligned}
\text { Audit fees }_{i t}= & \left.a+\beta_{1}(\text { IFRS })_{1}\right)_{i t}++\delta_{2}(\text { IFRS })_{i t}+\delta_{3}(\text { IFRS }+1)_{i t}+\delta_{4}(\text { IFRS }+2)_{i t} \\
& +\delta_{5}(\text { Audit lags })_{i t}+\delta_{6}(\text { Auditor switch })_{i t}+\delta_{7}(\text { Big } 4)_{i t} \\
& +\delta_{8}(\text { Firm size })_{i t}+\delta_{9}(\text { Profitability })_{i t}+\delta_{9}(\text { Return on assets })_{i t} \\
& +\delta_{10}(\text { Leverage })_{i t}+\varepsilon_{i t}
\end{aligned}
$$

$$
\begin{aligned}
\text { Audit lags }_{i t}= & \left.a+\beta_{1}(\text { IFRS })_{1}\right)_{i t}++\delta_{2}(\text { IFRS })_{i t}+\delta_{3}(\text { IFRS }+1)_{i t}+\delta_{4}(\text { IFRS }+2)_{i t} \\
& +\delta_{5}(\text { Audit fees })_{i t}+\delta_{6}(\text { Auditor switch })_{i t}+\delta_{7}(\text { Big } 4)_{i t} \\
& +\delta_{8}(\text { Firm size })_{i t}+\delta_{9}(\text { Profitability })_{i t}+\delta_{9}(\text { Return on assets })_{i t} \\
& +\delta_{10}(\text { Leverage })_{i t}+\varepsilon_{i t}
\end{aligned}
$$

where $i$ and $t$ represent firm and time, respectively, and $\varepsilon_{\text {it }}$ is the associated error. All variables are defined in Table 1. IFRS.

Due to the high transitional cost, we expect audit fees to increase during the IFRS-1 and

IFRS +1 and IFRS +2 are the test variables for measuring whether there are higher audit fees.

The control variables were selected based on prior literature. As presented by Hay et al. (2006), it is documented in the existing literature that the size of a company is an essential determinant of how much an auditor charged. Coffie and Bedi (2019) also found a significant relationship between firm size and audit fees. Hence, we expect that Firm size will have a positive impact on audit fees. Auditing time measures the number of days between the balance sheet date and the signature date of the audit report and is an indicator of audit efficiency. Griffin et al. (2009), Knechel and Pyne (2001) argue that a longer period signals difficulty during the auditing process, which is likely to cause an uplift in audit fees. Existing literature, such as Griffin et al. (2009) and Simunic (1980) asserts that client audit fees are also affected by the complexity and risk of the company. Simunic (1980) finds that fees are usually high for less liquid, low return and high leveraged companies as these companies are more likely to have going concern issues that increase auditor's liabilities. Therefore, following Averhals et al. (2020), we proxy company risk with leverage (Leverage) and whether the company made a profit or loss (Profitability). We also include Return on assets as a control for performance. With a global network of operations, the Big4 has built a reputation and quality that attracts premium audit fees (DeAngelo, 1981; Griffin et al., 2009; Hay et al., 2006; Higgins et al., 2016). We use dummy variable $1=$ Big4 and $0=$ non-Big4 to capture the auditor's premium.

Although there is no clear direction on the impact of auditor change (Auditor switch) on audit fees (Craswell and Francis, 1999; Griffin et al., 2009; Ghosh and Lustgarten, 2010), we expect a positive association as most companies in Africa are likely to change to Big4 during 


\begin{tabular}{|c|c|c|c|}
\hline Variable name & Measurement & Sources & npact of IFRS \\
\hline Audit fees & Natural log of total audit fees & Annual reports & \\
\hline Auditing time & $\begin{array}{l}\text { It is measured as the days between the balance sheet date and the } \\
\text { signature date of the audit report }\end{array}$ & Annual reports & \\
\hline IFRS & $\begin{array}{l}\text { IFRS adoption is defined as a categorical variable which equals } 1 \\
\text { if the company prepares IFRS report or } 0 \text { - otherwise }\end{array}$ & Annual reports & \\
\hline Auditor switch & $\begin{array}{l}\text { Is equal to } 1 \text { if, in a year, the firm uses a different audit firm to } \\
\text { audit its financial report compare to the prior year }\end{array}$ & Annual reports & 9 \\
\hline Big4 & $\begin{array}{l}\text { Indicates the type of auditor that audit company financial } \\
\text { statements and is a discrete variable that takes on } 1=\text { Big } 4,0= \\
\text { non-Big } 4\end{array}$ & Annual reports & \\
\hline Firm size & Natural logarithm of the total asset & Annual reports & \\
\hline Profitability & $\begin{array}{l}\text { Dummy variable equal to } 1 \text { if the company made a profit or } 0= \\
\text { loss }\end{array}$ & Annual reports & \\
\hline Return on assets & Calculated as the ratio of net profit before tax to total assets & Annual reports & \\
\hline Leverage & $\begin{array}{l}\text { Financial leverage is measured as the ratio of total liability to total } \\
\text { assets }\end{array}$ & Annual reports & $\begin{array}{r}\text { Description and } \\
\text { sources of variables }\end{array}$ \\
\hline
\end{tabular}

IFRS adoption. This is because the Big4 are perceived to have knowledge and experience in IFRS (Khlif et al., 2016; Wieczynska, 2016).

\section{Results and discussions}

\subsection{Univariate results}

The descriptive statistics of the variables used in the study are presented in Table 2 . The table also includes $t$-test on the variables between early and late adopters. For the purpose of comparison and $t$-test analysis, the audit fess and firm size (total assets) were converted to US dollars before the log transformation. However, in the regression analyses, we use the log form of the local currency to avoid bias results due to the currency conversion. The $p$-value of the $t$-test shows that the characteristics of the firms from early and late adopters are nearly indistinguishable except for audit fees, audit time and auditor switch. The high standard deviation of firm size measured by total assets explains the wide range in the firm

\begin{tabular}{|c|c|c|c|c|c|c|c|}
\hline \multirow[b]{2}{*}{ Variable } & \multicolumn{3}{|c|}{ Early adopters } & \multicolumn{3}{|c|}{ Late adopters } & \multirow{2}{*}{$\begin{array}{l}\text { T-test } \\
P \text {-value }\end{array}$} \\
\hline & Mean & Median & Std. & Mean & Median & Std. & \\
\hline Audit fees & 4.195 & 3.026 & 5.879 & 3.765 & 2.927 & 4.091 & 0.009 \\
\hline Auditing time & 94 & 79 & 38 & 89 & 93 & 45 & 0.045 \\
\hline Audit switch & 0.196 & 0.155 & 0.767 & 0.113 & 0.096 & 0.891 & 0.091 \\
\hline Big4 & 0.836 & 0.853 & 0.090 & 0.811 & 0.809 & 0.276 & 0.213 \\
\hline Firm size & 18.778 & 20.381 & 15.712 & 17.001 & 19.872 & 16.96 & 0.119 \\
\hline Return on assets & 0.181 & 0.230 & 0.379 & 0.175 & 0.216 & 0.418 & 0.347 \\
\hline Profitability & 0.813 & 0.761 & 0.231 & 0.890 & 0.801 & 0.131 & 0.679 \\
\hline Leverage & 0.351 & 0.451 & 0.675 & 0.423 & 0.392 & 0.543 & 0.193 \\
\hline
\end{tabular}

Notes: For the purpose of comparison and t-test analysis, the audit fees and firm size (total assets) are were converted to \$before the log transformation. In the regression analyses, we use the log form of the local currency

Table 2.

Descriptive statistics 
IJAIM

30,1

10

size. Also, it shows the diversity of the sample companies across different levels of firm development. With more than $85 \%$ of our sample observation reporting profit, there is a low operational risk in the sample. The dominance of the Big4 in Africa is reflected in the sample, with the Big4 having more than $75 \%$ of the market share in the sample countries.

To further demonstrate the difference in audit fees and auditing time around IFRS adoption between early adopters and late adopters, we present the marginal means over the five years. As seen in Figure 1, there is a large change in audit fees at the transition and adoption year for early adopters than late adopters. However, in the late adopters, the increase in audit fees around the same time is relatively small compared to early adopters. The trend of the marginal auditing time, as presented in Figure 2, mimic that of Figure 1, affirming an increase in audit fees through an increase in auditing time.

Table 1 Presents the pearson pairwise correlation matrix between variables. There is a significant positive correlation between the indicative variable (IFRS) and audit fees. Similarly, there is a positive correlation between audit fees and audit time, as well as between IFRS and auditor switch. These relationships confirm the impact of IFRS on audit fees, audit time and auditor switch. None of the correlation matrices is greater than the multi-collinearity threshold of 0.6 (Field, 2000; Gujarati, 2003; Tabachnick and Fidell, 2007).

\subsection{International financial reporting standards and audit fees}

Prior studies on audit fees (Griffin et al., 2009; Higgin et al., 2016) used cross-sectional data and the few that attempt trends in the fees use pooled regressions (Menon and Williams, 2001; McMeeking et al., 2007). We update and extend the literature by using panel data from 314 companies over 5-years with industry effects.

To fully comprehend the impact of IFRS adoption on audit fees, we use hierarchical multi-level regression beginning with regressing audit fees on IFRS adoption without control, then with controls and finally including industry effect. The results are presented in Table 3. Columns 1-3 contains the results of early adopters. The coefficient of IFRS is positive and significant at $5 \%$ or less in all three columns, suggesting that the use of IFRS is associated with an increase in audit fees. In Columns 3-6, we present the results of late adopters. Although the coefficient of IFRS is positive, it is small and insignificant except for

Figure 1.

Marginal audit fee for pre- and postadoption

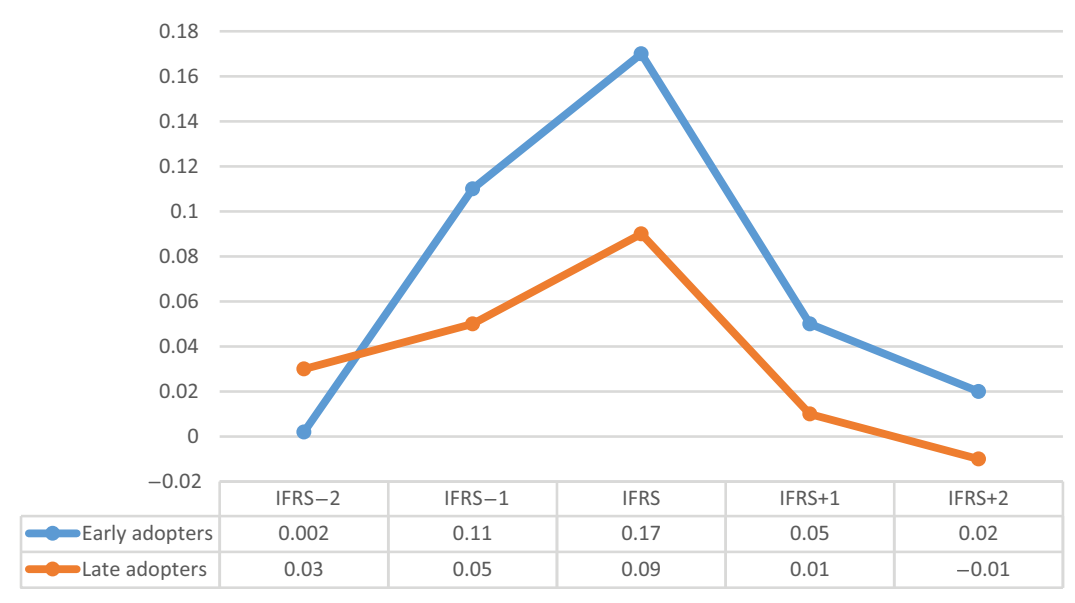




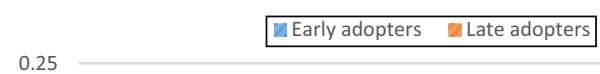

0.25

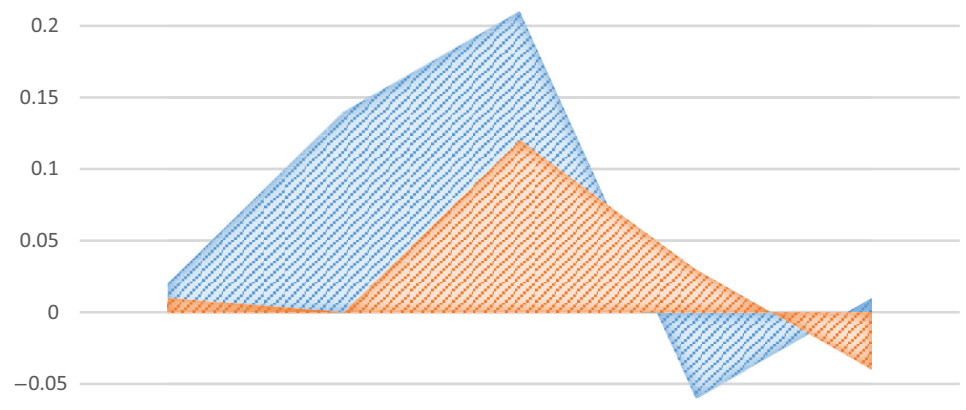

\begin{tabular}{|c|c|c|c|c|c|}
\hline-0.1 & IFRS -2 & IFRS-1 & IFRS & IFRS +1 & IFRS +2 \\
\hline Early adopters & 0.02 & 0.14 & 0.21 & -0.06 & 0.01 \\
\hline Late adopters & 0.01 & 0 & 0.12 & 0.03 & -0.04 \\
\hline
\end{tabular}

Impact of IFRS

on audit fees

11

Figure 2.

Marginal auditing time in pre- and postadoption

\begin{tabular}{|c|c|c|c|c|c|c|c|c|}
\hline Variables & 1 & 2 & 3 & 4 & 5 & 6 & 7 & 8 \\
\hline IFRS & 1.00 & & & & & & & \\
\hline Audit fees & 0.432 **** & 1.00 & & & & & & \\
\hline Auditing time & $0.391^{* * * *}$ & $0.1885^{* * *}$ & 1.00 & & & & & \\
\hline Audit switch & $0.154^{* *}$ & 0.054 & 0.022 & 1.00 & & & & \\
\hline Big4 & 0.000 & $0.524 * * *$ & -0.007 & 0.089 & 1.00 & & & \\
\hline Firm size & 0.042 & $0.278^{* * * *}$ & $0.065^{* *}$ & -0.022 & $0.1394 * *$ & 1.00 & & \\
\hline Return on assets & -0.045 & 0.117 & -0.336 & $-0.134^{*}$ & $0.250 * *$ & $0.208^{* *}$ & 1.00 & \\
\hline Profitability & -0.052 & -0.167 & 0.114 & $-0.216^{* * * *}$ & $-0.216^{* * *}$ & $-0.23^{* * *}$ & $-0.472 * * *$ & 1.00 \\
\hline Leverage & 0.0696 & 0.012 & $0.016^{*}$ & 0.0598 & 0.0598 & 0.061 & 0.107 & -0.02 \\
\hline
\end{tabular}

Notes: Significant levels - $* * *=1 \% ; * *=5 \% ; *=10 \%$

Table 3.

Pearson pairwise correlation matrix of variables

Column 4. Therefore, in comparison with early adopters, the results of Table 3 indicate that the adoption of IFRS is more likely to increase audit fees significantly only in the earlier days of adoption. These results are consistent with Higgins et al., 2016); Lin and Yen (2016), Kim et al. (2012); Vieru and Schadewitz (2010), Griffin et al. (2009), which found increase audit fees around IFRS adoption, mostly for countries that adopted earlier.

Put differently; early adopters paid a higher price for being the first users of IFRS. Arguably, as a new set of standards, IFRS was perceived to be more involving in the earlier days; hence, preparers and auditors required more time to understand and implement it. More so, early adopters may have had more incentive to implement IFRS for its full perceived benefits, such as increased transparency and comparability, which might not be the case of late adopters who might be implementing IFRS due to global pressure. Another plausible reason is the transfer of IFRS experience from early adopters to late adopters by global accounting firms. As stated earlier in Section 2, unlike other countries in prior studies, the audit market of Africa is highly dominated by the Big4; hence, it is more logical to expect 
IJAIM 30,1

they used their IFRS experience and resources from elsewhere to beat the competition in late adopting countries.

The results of most control variables are consistent with standard assumptions. For example, Consistent with prior literature (Higgins et al., 2016; Griffin et al., 2009) and expectation, the coefficient of Firm size is positive and significant, indicating that audit fees increase as the company grows. Also, the Big4 is positive and significant, indicating that global firms charge high audit fees than national and small firms.

\subsection{International financial reporting standards and auditing time}

To further understand the impact of IFRS adoption on the audit market, we test the relationship between IFRS adoption and auditing time. By simultaneously examining the effect of IFRS on audit fees and auditing time, we indirectly test the channel through which IFRS increase audit fees. This is another point of difference between our study and that of existing literature. The regression results where the auditing time is the dependent variable are reported in Table 5. Following the hierarchical multi-level regression used in the audit fees, we run the regression in three stages; without controls, with controls and with industry effect. The results of early adopters are presented in Columns 1-3 and that of late adopters in Columns 4-6.

Consistent with audit fees results in Table 4, the coefficient of IFRS in Columns 1-3 is positive and highly significant at 1\%. Our results are consistent with Habib (2015), Amirul and Salleh (2014), Walker and Hay (2013) and Habib and Bhuiyan (2011) which find an increase in audit reporting time around IFRS adoption. The results indicate that it took a significant number of days for auditors to provide a report on IFRS financial statements. Given that audit fee is a function of auditing time, the results explain the increase in audit fees around IFRS adoption. Similarly, we find the relationship between audit reporting lags and IFRS adoption to be very weak in the case of late adopters, which confirms the insignificant impact of IFRS adoption on audit fees in Table 4. With the Big4 having a nearly monopoly in the audit market of Africa, we argue that the weak result of late adopters is due to the transfer of knowledge and experience by the auditors from early adopters. As global accounting firms, the Big4 have share resources and expertise across member firms in different countries; hence, they could easily have persons with IFRS experience to fast track issues in late adopting countries. Furthermore, preparers in late adopting countries may have had more exposure to IFRS prior to the adoption compared with preparers in early adopting countries.

\subsection{Accounting for international financial reporting standards pre-and post-periods}

We admit that the simple binary nature of IFRS is likely to cause bias in the results as it pools the effects of any adoption costs with other years (Higgins et al., 2016). Therefore, we overcome this limitation by disaggregating each IFRS year into a separate dummy variable.

The results are presented in Table 6 . Columns 1 and 2 contain the results of early adopters on audit fees and auditing time, respectively. In both audit fees and auditing time, the coefficient of IFRS-1, IFRS0 and IFRS+1 is positive and significant, indicating an increase in audit time corresponding to an increase in audit fees around the transition to IFRS and one-year post-IFRS period. In contrast, the results of late adopters in Columns 3 and 4 show that the increase in audit fees and time is significant only at the adoption year. That is, audit fees and auditing time were significantly higher only in the year in which the firm prepared its first IFRS financial statement. Early adopters may have had a radical change in accounting systems, including the high cost of training staff due to the lack of prior knowledge of IFRS, and the perceived complexities around it. Late adopters had the 
ง लंखं

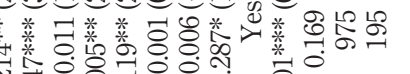


IJAIM

30,1

14

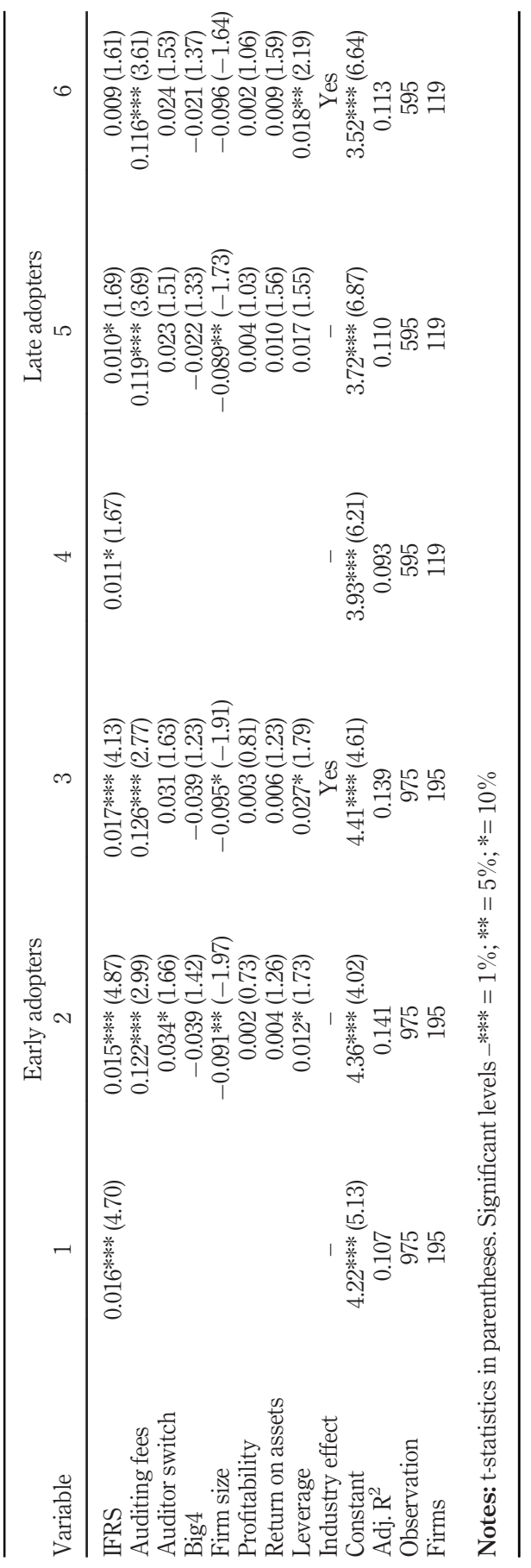

Table 5.

Regression results on auditing time 


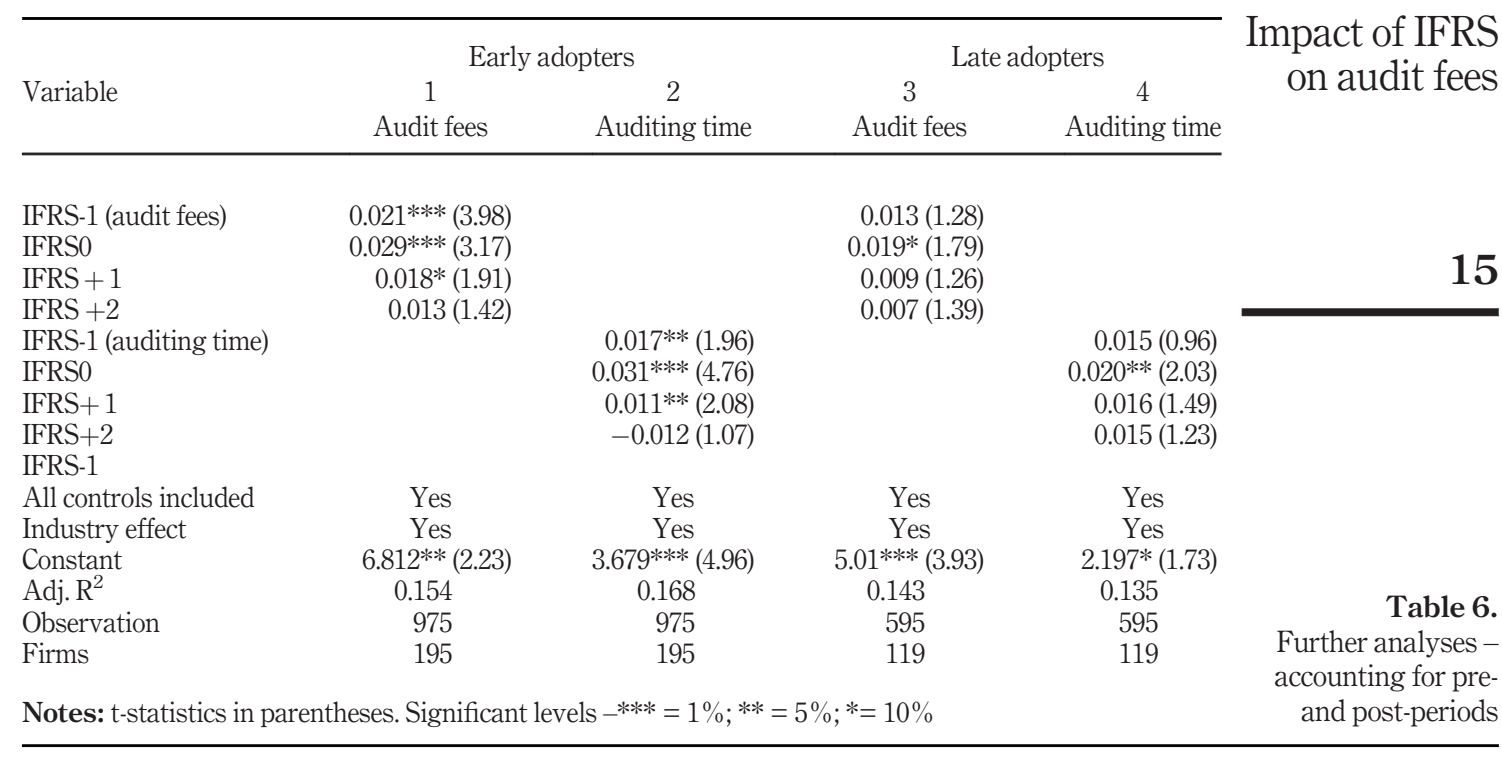

advantage of learning from earlier adopters of the actual requirements of IFRS without excessive investment.

The results in Table 6, therefore, provide more evidence and confirm our findings that the IFRS adoption is associated with an increase in audit fees, and auditing time is more pronounced in early adopters and barely non-existing in late adopters.

\subsection{Robustness check}

To further check the robustness of our findings, we use the marginal means of audit fees, and auditing time as an alternative measurement to the dependent variable. The marginal means are calculated as the year on year changes in audit fees or audit time. In the case of audit fees, we use the inflation-adjusted figures. The results are presented in Table 7. Columns 1 and 2 contain the estimation results of early adopters while that of late adopters are presented in Columns 3 and 4 . The results are not qualitatively different from that of the main results in Table 4; hence, our findings that the effect of IFRS adoption on audit fees and auditing time are robust to an alternative measurement of variables.

\section{Conclusion}

There are plentiful and almost unanimous findings that IFRS is a complex set of standards that increases the cost of auditing to a firm (Cameran and Peroti, 2014; De George et al., 2013; Griffin et al., 2009; Hassan et al., 2014; Higgins et al., 2016; Lin and Yen, 2016, on China; Rished and Al-Saeed, 2014; Yaacob and Che-Ahmad, 2012). However, all these findings are based on a sample of early adopters with no references to late adopters. As suggested by Key and Kim (2020), the experience, exposure and incentives of late adopters are quite different from early adopters; hence, the consequence could also be different. Therefore, in this paper, we have use the unique settings of IFRS adoption by two different African countries to examine whether the effect of IFRS on audit fees and auditing time differs between early and late adopters. Africa provides a suitable setting for the analysis because 


\section{IJAIM 30,1}

\section{Table 7.}

Robustness check using marginal fees and marginal auditing time

\begin{tabular}{lcccc}
\hline & \multicolumn{2}{c}{ Early adopters } & \multicolumn{2}{c}{ Late adopters } \\
Variable & 1 & 2 & 3 & 4 \\
& Audit fees & Auditing time & Audit fees & Auditing time \\
\hline IFRS & $0.232^{* * *}(2.63)$ & $0.017^{* * *}(4.13)$ & $0.035(1.51)$ & $0.009(1.61)$ \\
Auditing time & $0.147^{* * *}(3.09)$ & & $0.142^{* *}(2.16)$ & \\
Audit fees & & $0.126^{* * *}(2.77)$ & & $0.119^{* * *}(3.61)$ \\
Audit switch & $0.026(1.57)$ & $0.037^{*}(1.69)$ & $0.012(1.51)$ & $0.027(1.51)$ \\
Big4 & $0.005^{* *}(2.33)$ & $-0.037(1.27)$ & $0.001(1.45)$ & $-0.023(1.32)$ \\
Firm size & $0.129^{* *}(2.31)$ & $-0.093^{*}(-1.89)$ & $0.109^{* * *}(4.19)$ & $-0.086^{*}(-1.67)$ \\
Profitability & $0.001(0.89)$ & $0.003(0.82)$ & $0.004(1.06)$ & $0.001(1.17)$ \\
Return on assets & $0.006(1.49)$ & $0.005(1.23)$ & $0.009(1.49)$ & $0.007(1.57)$ \\
Leverage & $0.183^{*}(1.68)$ & $0.025^{*}(1.79)$ & $0.175^{* *}(2.26)$ & $0.018^{* *}(2.29)$ \\
Industry effect & Yes & Yes & Yes & Yes \\
Constant & $2.01 * * *(3.11)$ & $1.13^{* * *}(2.31)$ & $2.26^{* *}(2.11)$ & $1.22^{* * *}(2.69)$ \\
Adj. R $^{2}$ & 0.119 & 0.297 & 0.115 & 0.120 \\
Observation & 975 & 975 & 595 & 595 \\
Firms & 195 & 195 & 119 & 119 \\
& & & &
\end{tabular}

Notes: t-statistics in parentheses. Significant levels $-* * *=1 \% ; * *=5 \% ; *=10 \%$

of the low adoption in the region and significant different adopting years between the countries. Also, the region has not attracted much attention in the IFRS-auditing effect literature. South Africa adopted IFRS in 2005 and is labelled as early adopters while the adoption by Nigeria in 2012 is considered as late adopting.

The results speak in favour of the argument that the relationship between IFRS adoption and audit fees, as well as auditing time, differ between early adopters and late adopters. Specifically, we find that early adopters experience a significant increase in audit fees and time due to IFRS adoption. However, in the case of late adopters, although audit fees increase, it is barely significant. Our results imply that early adopters of IFRS paid a premium for being the first users of the standards, through the increase in audit fees and audit timing. In further analyses, we find that the positive relationship between IFRS and audit fees and auditing time is significant in transition year through to one-year post-IFRS adoption. But in the case of late adopters, the relationship is significant at only adoption year. The results are robust to an alternative measurement of audit fees and auditing time.

These contrasting findings between early and late adopters can be attributed to the incentive to adopt and exposure to IFRS. We argue that early adopters had intrinsic value to adopt IFRS for its benefit, hence, invested heavily to realised such benefits. Late adopters, on the other hand, were probably influenced by the external forces and the global drive of harmonisation, leading to less interest to invest more money and time in the implementation of IFRS. Another reason is that early adopters did not have much exposure and experience to IFRS compare with late adopters, where some auditors might have work on the IFRS system in other countries. This is particularly true in the case of Africa, where the Big4, which have a global network of accounting firms, audit more than $80 \%$ of listed firms.

Our findings are relevant to policymakers, regulators and practitioners as it shows that cost of IFRS is less for late adopters. This finding informs policymakers, especially in nonIFRS countries, that the auditing cost associated with IFRS is likely to be less, and hence, the benefit will probably outweigh the cost. Our study, therefore, encourages non-adopting IFRS to consider the IFRS because the cost will be less than the early adopters. Given these 
findings, we suggest future studies re-examine IFRS consequences in other areas, such as reporting quality, earnings management and firm value with attention to early and late adopters.

\section{Notes}

1. Not until 2019 when the Organisation pour I'Harmonisation en Afrique du Droit des Affaires (OHADA) countries mandated IFRS, only 22 out of 54 African countries have fully adopted IFRS (IFRS Foundation).

2. The UK which is also considered as world leader in the strength of accounting and auditing environment had over 350,000 accountants and 6,010 audit firms as at 2016 (Financial Reporting Council, 2017).

3. For instance, in the UK, the Big4 audited on average of $70 \%$ of listed companies on the main market (Financial Reporting Council, 2017).

\section{References}

Afify, E. (2009), "Determinants of audit report lag: Does implementation of corporate governance have any impact?", Journal of Applied Accounting Research, Vol. 10 No. 1, pp. 56-86.

Agyei-Boapeah, H., Machokoto, M., Amankwah-Amoah, J., Tunyi, A. and Fosu, S. (2020), "IFRS adoption and firm value: African evidence", Accounting Forum, pp. 1-24.

Amirul, S. and Salleh, M. (2014), "Convergence to IFRS and audit report lag in Malaysia", Research Journal of Finance and Accounting, Vol. 5 No. 23, pp. 9-16.

Asien, E.N. (2014), "Exploring the state of the audit market in Nigeria", African J. Of Accounting, Auditing and Finance, Vol. 3 No. 4, pp. 287-307.

Averhals, L., Van Caneghem, T. and Willekens, M. (2020), "Mandatory audit fee disclosure and price competition in the private client segment of the belgian audit market", Journal of International Accounting, Auditing and Taxation, Vol. 40, p. 100337.

Bamber, M., Bamber, S. and Schoderbek, P. (1993), "Audit structure and other determinants of audit report lag: an empirical analysis", Auditing: A Journal of Practice and Theory, Vol. 12 No. 1, pp. 1-23.

Basioudis, I.G., Papakonstantinou, E. and Geiger, M.A. (2008), "Audit fees, Non-Audit fees and auditor Going-Concern reporting decisions in the United Kingdom”, Abacus, Vol. 44 No. 3, pp. 284-309.

Blankley, A., David, H. and Jason, M. (2014), "The relationship between audit report lags and future restatements", Auditing: A Journal of Practice and Theory, Vol. 33 No. 2, pp. 27-57.

Bonson-Ponte, E., Escobar-Rodriguez, T. and Borrero-Dominguez, C. (2008), "Empirical analysis of delays in the signing of audit reports in Spain", International Journal of Auditing, Vol. 12 No. 2, pp. 129-140.

Boolaky, P., Tawiah, V. and Soobaroyen, T. (2020), "Why do African countries adopt IFRS? An institutional perspective", The International Journal of Accounting, Vol. 55 No. 1, pp. 2050005.

Bruce, R. (2011), "Interview with van rooyen, zubaidur rahman and Paul pacter", Africa embraces IFRSs, available at: www.ifrs.org/news/features/Pages/africaembraces-ifrss.aspx

Cameran, M. and Perotti, P. (2014), "Audit fees and IAS/IFRS adoption: evidence from the banking industry", International Journal of Auditing, Vol. 18 No. 2, pp. 155-169.

Capkun, V., Collins, D. and Jeanjean, T. (2016), "The effect of IAS/IFRS adoption on earnings management (smoothing): a closer look at competing explanations", Journal of Accounting and Public Policy, Vol. 35 No. 4, pp. 352-394. 
IJAIM 30,1

Cho, M., Ki, E. and Kwon, S. (2015), "The effects of accruals quality on audit hours and audit fees", Journal of Accounting, Auditing and Finance, Vol. 32 No. 3, pp. 372-400.

Choi, W. and Yoon, S. (2014), "Effects of IFRS adoption, big N factor, and the IFRS-related consulting services of auditors on audit fees: the case of Korea", Asian Journal of Business and Accounting, Vol. 7 No. 1, pp. 55-80.

Coffie, W. and Bedi, I. (2019), "The effects of IFRS adoption and firm size on audit fees in financial institutions in Ghana", Accounting Research Journal, Vol. 32 No. 3, pp. 436-453.

Craswell, A. and Francis, J. (1999), "Pricing initial audit engagements: a test of competing theories", The Accounting Review, Vol. 74 No. 2, pp. 201-215.

Dayanandan, A., Donker, H., Ivanof, M. and Karahan, G. (2016), "IFRS and accounting quality: legal origin, regional, and disclosure impacts", International Journal of Accounting and Information Management, Vol. 24 No. 3, pp. 296-316.

De Martinis, M. and Houghton, K. (2019), "The business risk audit approach and audit production efficiency", Abacus, Vol. 55 No. 4, pp. 734-782.

DeAngelo, L.E. (1981), "Auditor size and audit quality”, Journal of Accounting and Economics, Vol. 3 No. 3, pp. 183-199.

De George, E., Ferguson, C. and Spear, N. (2013), "How much does IFRS cost? IFRS adoption and audit fees", The Accounting Review, Vol. 88 No. 2, pp. 429-462.

Diehl, A. (2010), "The real cost of IFRS: the relationship between IFRS implementation and audit, tax, and other auditor fees", International Research Journal of Finance and Economics, Vol. 37, pp. 96-101.

Dinh, N. and Piot, C. (2014), "IFRS adoption in Europe and audit market concentration", available at: http://ssrn.com/abstract 1/42398463; 10.2139/ssrn.2398463 (accessed February 2017).

Ettredge, M., Li, C. and Sun, L. (2006), "The impact of SOX section 404 internal control quality assessment on audit delay in the SOX era", Auditing: A Journal of Practice and Theory, Vol. 25 No. 2, pp. 1-23.

Field, A. (2000), Discovering Statistics Using SPSS for Windows, Sage Publications, Thousand Oaks, CA.

Financial Reporting Council (2017), "Key facts and trends in the accountancy profession", available at: www.frc.org.uk/getattachment/77fc8390-d0d1-4bfe-9938-8965ff72b1b2/Key-Facts-and-Trends2017.pdf

Gerakos, J. and Syverson, C. (2015), "Competition in the audit market: policy implications", Journal of Accounting Research, Vol. 53 No. 4, pp. 725-775.

Ghosh, A. and Lustgarten, S. (2010), "Pricing of initial audit engagements by large and small audit firms", Contemporary Accounting Research, Vol. 23 No. 2, pp. 333-368.

Griffin, A., Lont, H. and Sun, Y. (2009), "Governance regulatory changes, international financial reporting standards adoption, and New Zealand audit and non-audit fees: empirical evidence", Accounting and Finance, Vol. 49 No. 4, pp. 697-724.

Gujarati, D. (2003), Basic Econometrics, (4th ed.). McGraw-Hill.

Habib, A. (2012), "Non-Audit service fees and financial reporting quality: a meta-analysis", Abacus, Vol. 48 No. 2, pp. 214-248.

Habib, A. (2015), “The new chinese accounting standards and audit report lag”, International Journal of Auditing, Vol. 19 No. 1, pp. 1-14.

Habib, A. and Bhuiyan, B. (2011), "Audit firm industry specialization and the audit report lag”, Journal of International Accounting, Auditing and Taxation, Vol. 20 No. 1, pp. 32-44.

Harber, M. and Marx, (2019), "An analysis of the possible impact of mandatory audit firm rotation on the transformation and market concentration of the South African audit industry", Journal of Economic Financial Sciences, Vol. 12 No. 1, pp. 1-11. 
Harber, M. and West, S. (2017), "An analysis of the IRBA consultation paper on mandatory audit firm rotation together with key switch responses", 2017 Southern African Accounting Association (SAAA) Biennial International Conference Proceedings (ISBN 978-0-620-74762-2).

Impact of IFRS on audit fees

Hassan, G.A.O., Crawford, L. and Power, D. (2014), "Audit fees, IFRS adoption and the recent global financial crisis", available at: www.file:///C:/Documents $\% 20$ and $\% 20$ Settings/NACEUR/Mes $\%$ 20documents/Downloads/Audit_fees_IFRS_adoption_and_the_recent_global_financial_crisis_ pdf\% 20(4).pdf (accessed February, 2017).

Hay, D., Knechel, W. and Wong, N. (2006), "Audit fees: a meta-analysis of the effect of supply and demand attributes", Contemporary Accounting Research, Vol. 23 No. 1, pp. 141-191.

Higgins, S., Lont, D. and Scott, T. (2016), "Longer term audit costs of IFRS and the differential impact of implied auditor cost structures”, Accounting and Finance, Vol. 56 No. 1, pp. 165-203.

Houqe, N. (2018), "A review of the current debate on the determinants and consequences of mandatory IFRS adoption", International Journal of Accounting and Information Management, Vol. 26 No. 3, pp. 413-442.

Independent Regulatory Board for Auditors (2016), “The IRBA consultation paper”, www.irba.co.za/ news-headlines/press-releases (access 2019).

Isaboke, C. and Chen, Y. (2019), "IFRS adoption, value relevance and conditional conservatism: evidence from China", International Journal of Accounting and Information Management, Vol. 27 No. 4, pp. 529-546.

Key, K.G. and Kim, J.Y. (2020), "IFRS and accounting quality: Additional evidence from korea”, Journal of International Accounting, Auditing and Taxation, Vol. 39, pp. 100306.

Khlif, H., Achek, I. and Achek, I. (2016), "IFRS adoption and auditing: a review", Asian Review of Accounting, Vol. 24 No. 3, pp. 338-361.

Khlif, H. and Samaha, K. (2014), "Internal control quality, Egyptian standards on auditing and external audit delays: evidence from the egyptian stock exchange", International Journal of Auditing, Vol. 18 No. 2, pp. 139-154.

Kim, J., Liu, X. and Zheng, L. (2012), "The impact of mandatory IFRS adoption on audit fees: theory and evidence", The Accounting Review, Vol. 87 No. 6, pp. 2061-2094.

Knechel, R. and Pyne, J. (2001), "Additional evidence on audit report lag", Auditing: A Journal of Practice and Theory, Vol. 20 No. 1, pp. 137-146.

Lambert, A., Jones, L. and Brazel, F. (2013), "Unintended consequences of accelerated filings: are involuntary reductions in audit delay associated with reductions in earnings quality?", Working paper, Lehigh University, George Mason University and North Carolina University.

Lassou, P.J.C. and Hopper, T. (2016), "Government accounting reform in an ex-French African colony: the political economy of neocolonialism”, Critical Perspectives on Accounting, Vol. 36, pp. 39-57, available at: https://doi. org/10.1016/j.cpa.2015.10.006

Lee, Y., Mande, V. and Son, M. (2009), "Do lengthy auditor tenure and the provision of non-audit services by the external auditor reduce audit report lags?”, International Journal of Auditing, Vol. 13 No. 2, pp. 87-104.

Lin, L. and Yen, R. (2016), "The effects of IFRS experience on audit fees for listed companies in China”, Asian Review of Accounting, Vol. 24 No. 1, pp. 43-68.

Liu, C., Yao, L.J., Hu, N. and Liu, L. (2011), "The impact of IFRS on accounting quality in a regulated market: an empirical study of China", Journal of Accounting, Auditing \& Finance, Vol. 26 No. 4, pp. 659-676, available at: https://doi. org/10.1177/0148558X11409164

McMeeking, K.P., Peasnell, K.V. and Pope, P.F. (2007), "The effect of large audit firm mergers on audit pricing in the UK", Accounting and Business Research, Vol. 37 No. 4, pp. 301-319.

Menon, K. and Williams, D.D. (2001), "Long-term trends in audit fees", Auditing: A Journal of Practice and Theory, Vol. 20 No. 1, pp. 115-136. 
IJAIM 30,1

Miah, M.S., Jiang, H., Rahman, A. and Stent, W. (2020), “Audit effort, materiality and audit fees: Evidence from the adoption of IFRS in Australia”, Accounting Research Journal, Vol. 33 No. 1, pp. 186-216.

Munsif, V., Raghunandan, K. and Rama, V. (2012), "Internal control reporting and audit report lag further evidence", Auditing: A Journal of Practice and Theory, Vol. 31 No. 3, pp. 203-218.

Research and Markets (2019), "The accounting sector in South Africa 2017", available at: www. researchandmarkets.com/reports/4807543/the-accounting-sector-in-south-africa-2019?utm _ source $=$ GNOM\&utm_medium $=$ PressRelease\&utm_code $=$ cqjpwr\&utm_campaign $=1280944+-+$ The + South + Africa + Accounting + Market $\% 2 \mathrm{c}+2019+$ Featuring $+\mathrm{PwC} \% 2 \mathrm{c}+$ Deloitte $\% 2 \mathrm{c}+\mathrm{EY}$ $\% 2 \mathrm{c}+\mathrm{KPMG} \% 2 \mathrm{c}+$ and + More\&utm_exec=joca220prd

Risheh, K. and Al-Saeed, M. (2014), "The impact of IFRS adoption on audit fees: evidence from Jordan”, Accounting and Management Information Systems, Vol. 13 No. 3, pp. 520-536.

Seetharaman, A., Gul, A. and Lynn, G. (2002), "Litigation risk and audit fees: evidence from U.K. firms cross-listed on U.S. markets", Journal of Accounting and Economics, Vol. 33 No. 1, pp. 91-115.

Simunic, D.A. (1980), "The pricing of audit services: theory and evidence", Journal of Accounting Research, Vol. 18 No. 1, pp. 161-190.

Tabachnick, B.G. and Fidell, L.S. (2007), Using Multivariate Statistics, Pearson/Allyn and Bacon, Boston, MA.

Tawiah, V. and Boolaky, P. (2019), "Determinants of IFRS compliance in Africa: analysis of stakeholder attributes", International Journal of Accounting and Information Management, Vol. 27 No. 4, pp. 573-599.

Velte, P. and Stiglbauer, M. (2012), "Audit market concentration and its influence on audit quality", International Business Research, Vol. 5 No. 11, pp. 146-161.

Vieru, M. and Schadewitz, H. (2010), "Impact of IFRS transition on audit and non-audit fees: evidence from small and medium-sized listed companies in Finland", The Finnish Journal of Business Economics, Vol. 14 No. 1, pp. 11-41.

Walker, A. and Hay, D. (2013), "Non-audit services and knowledge spill overs", Meditari Accountancy Research, Vol. 21 No. 1, pp. 32-51.

Wieczynska, M. (2016), "The 'big' consequences of IFRS: How and when does the adoption of IFRS benefit global accounting firms?”, The Accounting Review, Vol. 91 No. 4, pp. 1257-1283.

Yaacob, M. and Che-Ahmad, A. (2012), "Audit fees after IFRS adoption: evidence from Malaysia", Eurasian Business Review, Vol. 2 No. 1, pp. 33-48.

Zori, S. (2015), "To adopt or not to adopt? The transnational adoption of international financial reporting standards (IFRS) in africa”, $\mathrm{PhD}$ Thesis, available at: Universität_zu_Köln_kups.ub. uni-koeln.de/. . /Solomon_Zori_Dissertation_2015_To_Adopt_Or_... (accessed June 2017). 
Appendix

Impact of IFRS

on audit fees

Industry classifications

Early adopters

Late adopters

Basic materials, energy and industrials

Consumer discretionary and utilities

Financials

51

63

Health care

Real estate

Technology and telecommunications

Total

23
44
21
9
6
16
119

Corresponding author

Vincent Konadu Tawiah can be contacted at: vincent.tawiah@dcu.ie

For instructions on how to order reprints of this article, please visit our website: www.emeraldgrouppublishing.com/licensing/reprints.htm Or contact us for further details: permissions@emeraldinsight.com 